\title{
Determination of Optimum Ratio of Cationic Polymers and Small Interfering RNA with Agarose Gel Retardation Assay
}

\author{
Omer Aydin, Dilek Kanarya, Ummugulsum Yilmaz, and Cansu Ümran Tunç
}

\begin{abstract}
Nanomaterials have aroused attention in the recent years for their high potential for gene delivery applications. Most of the nanoformulations used in gene delivery are positively charged to carry negatively charged oligonucleotides. However, excessive positively charged carriers are cytotoxic. Therefore, the complexed oligonucleotide/nanoparticles should be well-examined before the application. In that manner, agarose gel electrophoresis, which is a basic method utilized for separation, identification, and purification of nucleic acid molecules because of its poriferous nature, is one of the strategies to determine the most efficient complexation rate. When the electric field is applied, RNA fragments can migrate through anode due to the negatively charged phosphate backbone. Because RNA has a uniform mass/charge ratio, RNA molecules run in agarose gel proportional according to their size and molecular weight. In this chapter, the determination of complexation efficiency between cationic polymer carriers and small interfering RNA (siRNA) cargos by using agarose gel electrophoresis is described. siRNA/cationic polymer carrier complexes are placed in an electric field and the charged molecules move through the counter-charged electrodes due to the phenomenon of electrostatic attraction. Nucleic acid cargos are loaded to cationic carriers via the electrostatic interaction between positively charged amine groups $(\mathrm{N})$ of the carrier and negatively charged phosphate groups $(\mathrm{P})$ of RNA. The N/P ratio determines the loading efficiency of the cationic polymer carrier. In here, the determination of N/P ratio, where the most efficient complexation occurs, by exposure to the electric field with a gel retardation assay is explained.
\end{abstract}

Key words Small interfering ribonucleic acid (siRNA), Agarose gel retardation assay, siRNA/cationic polymer carrier complex, Nanoparticles, N/P ratio, Gene delivery

\section{Introduction}

Regulation of a specific gene has been used for the treatment of a
wide range of diseases such as cardiovascular diseases [1], neurode-
generative diseases [2], and cancer [3]. RNA Interference (RNAi)
has become a powerful tool for gene silencing studies due to its
advantageous properties such as high specificity, effectiveness, a
minimum amount of side effect, and easy preparation [4]. RNAi
mechanism was first determined by Andrew Z. Fire, Craig 
C. Mello, and their colleagues [5]. As a result of their studies, they received the Nobel Prize in Physiology or Medicine in 2006. Interfering RNAs have the ability to silence target genes in cells [6]. At this silencing process, 18-31 nucleotides length small RNA molecules are introduced into cells and induce a sequence-specific gene silencing at the post-transcriptional level by blocking mRNAs containing a matched sequence.

siRNA is the most commonly used interfering RNA and has shown high potential as a therapeutic RNA for gene-based treatments [7]. It regulates the expression of various genes by binding to mRNAs in the cell cytoplasm and causing degradation of their mRNA target. The siRNA is double stranded in nature and is about 22 nucleotides in length. Its precursor is initially recognized by Dicer RNase and then incorporated with the RNA-induced silencing complex (RISC). The siRNA-RISC complex can bind the targeting region of the mRNA and lead to a sequence-specific cleavage with endonuclease Argonaute-2 (AGO2), thereby reducing the expression of the targeted protein [8].

Although siRNA has had particular interest in research, there are some limitations. The major limitations of siRNAs-based therapeutics are their rapid degradation by serum nucleases, poor cellular uptake due to the negatively charged backbone, rapid renal clearance following systemic delivery, off-target effects, and induction of immune responses [9]. In addition, even after siRNA is released from the endosome without being exposed to the lysosome and released into the cell cytoplasm, gene silencing of the siRNA may not be immediately observed [10]. Thereby, before the silencing therapeutic effect of siRNA begins, there is always an induction period due to the intracellular half-life of the target protein. The silencing effect of the given siRNA decreases over time owing to the natural degradation of the siRNA molecules in the cell. Moreover, the therapeutic effect persists for a limited time in rapidly dividing cells such as cancer cells, due to the continuous dilution of siRNA in the replication.

Bare siRNA molecules have poor cellular internalization and they need a carrier to enter cells, where their mechanism of action occurs. The major challenge in the delivery of nucleic acids is the availability of a suitable carrier for transferring siRNA to target cells. To do that, there are two main approaches such as viral and non-viral vectors [11]. The suitable vectors should provide a high degree of transfection for a long period without causing systemic toxicity and immunogenicity [12]. Despite the high transfection activity of viral vectors, possible damage to host genes, immune system stimulation, and infection potential limit its application for gene therapy [13].

To overcome these limitations different types of delivery systems have been designed such as lipid [14, 15], polymer [16], peptide $[17,18]$, dendrimer [19-21], and micelle [22] based 
vehicles. An ideal siRNA delivery system should be non-toxic, safe, and effective. Thus, many studies have focused on the development of non-viral vectors with minimal toxicity. Furthermore, the carrier systems should assure entrance of siRNA cargos to the cell cytoplasm without being interrupted by biological barriers such as serum, cell membrane, and endosome/lysosome [23]. In detail, the cell entry of siRNA/cationic polymer carriers is mostly facilitated by the mechanism known as "endocytosis" [10]. In particular, siRNA/cationic polymer carriers should be able to have endosomal escape. Otherwise, siRNA could be degraded in the acidic and enzymatic milieu of endosome/lysosome [24].

Cationic polymers and lipids have frequently been employed in research due to their advantages in gene delivery such as biodegradability, low cytotoxicity, structure variety, and easy scale-up production [25]. Therapeutic nucleic acid cargoes are loaded into the carrier systems mostly through the positive-negative charge interactions between positive charges of carrier and negative charges of phosphate groups in RNA. However, cationic polymer carriers with excess of positive charge may cause toxicity. Cationic carriers cause considerable disruption of cellular membrane integrity because of the negatively charged constitution of cell membrane [26]. Moreover, cationic nanocarriers induce cell necrosis due to the positive charge [27]. They also cause mitochondrial and lysosomal damage and formation of a high number of autophagosomes [28]. In order to overcome this problem, smart carriers have been developed not to cause cell membrane hydrolysis and necrosis so that they can deliver the therapeutic agents to the target site [29]. Although the benefits of nanocarriers in drug delivery have attracted much attention and great efforts have been made to investigate better cationic carriers, toxicity has always been the main problem of cationic carrier applications [30]. Because of this toxicity issue, the number of positive charges of polymer carriers should be kept low. In that case, the required therapeutic concentration of siRNA could not be achieved. Thus, $\mathrm{N} / \mathrm{P}$ ratio has a great importance for gene delivery. Consequently, it is essential to keep the $\mathrm{N} / \mathrm{P}$ ratio low, which indicates the complexation efficiency of the anionic therapeutic agents and the cationic carriers, in order to prevent cytotoxicity from excess amount of cationic polymer carriers. As a result, the main aim for optimum $\mathrm{N} / \mathrm{P}$ ratio is to carry the most efficient number of siRNA with minimum number of cationic polymer carriers.

To identify the optimum ratio of $\mathrm{N}$ and $\mathrm{P}$, the gel retardation assay commonly used for nucleic acid separation could be chosen for determination of $\mathrm{N} / \mathrm{P}$ ratio [31]. This technique is frequently utilized for the determination of DNA or RNA fragments based on their molecular weight [32]. The phosphate backbone of the DNA or RNA is negatively charged, and therefore RNA fragments 
migrate to the positively charged anode when placed in the electric field for separation, identification, and purification [33].

Agarose which, is a pure linear polymer obtained from seaweed, is frequently used for gel electrophoresis [34]. The polymer is boiled to dissolve in a buffer solution and polymerized in gel form by hydrogen bonding when left to cool at room temperature. There is no other component such as catalysts required than agarose. Therefore, preparing agarose gel is simple and fast. The advantages of agarose gel electrophoresis are being non-toxic gel medium, rapid, and easy to cast of gels and providing well separation of high molecular weight nucleic acids [35]. In addition, the samples can be recovered from the gel by melting or digesting the gel with any agarose enzyme or by treating a chaotropic salt [36].

The movement of molecules in an agarose gel depends on their size, charge, the type of electrophoresis buffer, and the pore size of the gel. In this method, siRNA is forced to migrate through an extremely cross-linked agarose base in response to an electric field. In the solution, the phosphate groups of the siRNA are negatively charged so the siRNA molecule migrates to the positive pole (Fig. 1).

This technique is also being used for determination of the complexation efficiency of siRNA/cationic polymer carriers. By adding a positively charged polymer to the siRNA, the overall charge of the complex is neutralized. Because of decreasing the negative charge density of siRNA complex, the movement of siRNA/cationic polymer carriers in the gel is getting difficult. If the complexation does not happen completely, for example, there are free forms of siRNA with siRNA/cationic polymer carriers, the free siRNAs travel far away than the complexation forms [37].

All in all, the movement of a siRNA/cationic polymer carrier complexation through a gel depends on (a) size of the complexation structure, (b) agarose concentration, (c) type of agarose, (d) applied voltage, (e) presence of staining dye, and (f) electrophoresis buffer type [38]. After running the samples in a suitable dye-containing gel, the complexed and free siRNA can be visualized under UV light.

\section{Materials}

1. siRNA.

2. Agarose.

3. Tris- $\mathrm{HCl}$.

4. Acetic acid or boric acid.

5. EDTA.

6. DNA Ladder. 


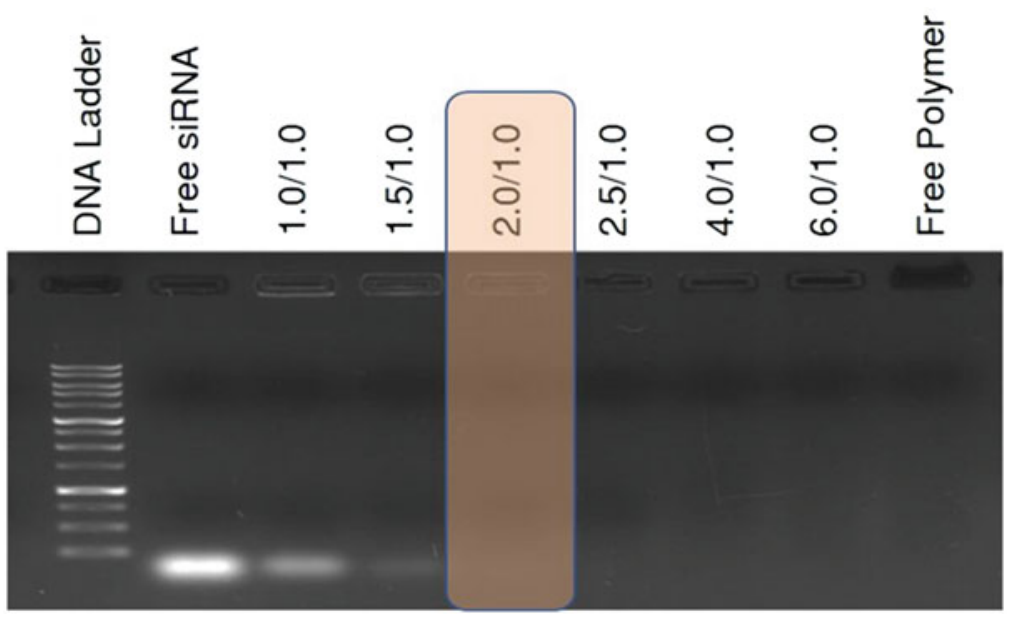

Fig. 1 Agarose gel retardation assay to evaluate siRNA binding efficiency of $15 \mathrm{kDa}$ cationic polymer complexation with siRNA at different N/P (amine/ phosphate) ratios. The gel retardation assay is set as the number of carriers is increasing, siRNA is kept constant. The orange-colored rectangle marking in the figure shows the optimal N/P ratio (2/1) which is siRNA completely complexed with the carriers

\section{Loading Dye.}

8. RedSafe nucleic acid staining solution.

9. Ethidium bromide.

10. $\mathrm{dH}_{2} \mathrm{O}$.

11. Microwave oven.

12. Gel casting device.

13. Glass beaker.

14. Graduated cylinder.

Prepare solutions with distilled water and nuclease-free water. Store all reagents (except siRNA and loading dye) at room temperature.

\subsection{Agarose Gel}

1. Preparation of tris acetate-ethylenediaminetetraacetic (TAE) buffer reagents: Prepare $50 \times$ TAE buffer $(\mathrm{pH} 8.0)$ with $40 \mathrm{mM}$ ethylenediaminetetraacetic (EDTA) disodium salt $\left(M_{\mathrm{W}}: 336.21 \mathrm{~g} / \mathrm{mol}\right), 2 \mathrm{mM}$ tris base $\left(M_{\mathrm{W}}: 121.14 \mathrm{~g} / \mathrm{mol}\right)$, 1 M Acetic Acid ( $\left.M_{\mathrm{W}}: 60.05 \mathrm{~g} / \mathrm{mol}\right)$ ( $\operatorname{see}$ Note 1$)$.

2. Preparation of stock solution $5.0150 \times$ TAE buffer $(\mathrm{pH} \mathrm{8.0)}$ : Weight $1.21 \mathrm{~g}$ of Tris base, $67.24 \mathrm{~g}$ of EDTA, and draw $285.95 \mathrm{~mL}$ of acetic acid and dissolve all of them in $5.0 \mathrm{~L}$ distilled water, carefully. Perform this step on the magnetic stirrer and adjust $\mathrm{pH} 8.0$ with hydrochloric acid $(\mathrm{HCl})($ see Note 2). Store the solution at room temperature. 
2.2 Polymer and SiRNA
3. Preparation of $1 \times$ TAE buffer: Draw $20.0 \mathrm{~mL}$ of $50 \times$ TAE buffer solution and complete it to final $1000.0 \mathrm{~mL}$ in a glass beaker (see Note 3 ).

4. Preparation of $1 \%$ agarose gel: Weight $1.0 \mathrm{~g}$ agarose powder, add $100.0 \mathrm{~mL}$ of electrophoresis buffer. Agarose powder is dissolved in the electrophoresis buffer to the desired concentration (see Note 4).

1. Preparation of polymer solution: Add $1.0 \mathrm{mg}$ of polymer in $1.0 \mathrm{~mL}$ of nuclease-free water. Store at $4{ }^{\circ} \mathrm{C}$.

2. Stock siRNA solution: Dissolve siRNA in nuclease-free water at a concentration of $50 \mu \mathrm{mol}$. Afterwards, allocate $800.0 \mu \mathrm{L}$ of stock siRNA solution into microcentrifuge tubes (see Note 5 ) and store at $-20{ }^{\circ} \mathrm{C}$.

\section{Methods}

\subsection{Calculation of Nitrogen to Phosphate (N/P) Ratio for Complexation for siRNA/Cationic Polymer Carriers}

3.1.1 Calculation of the Amine Groups of Polymer
Following the steps below, the number of siRNA, cationic polymers, and $\mathrm{N} / \mathrm{P}$ ratios will be calculated. It is good to create a table containing the amounts of siRNA, polymer, loading dye, and distilled water, which will be helpful for setting the experiment (see Table 1). After the calculation, the complexation siRNA/cationic polymer carriers at the different $\mathrm{N} / \mathrm{P}$ ratios are loaded into gel wells, run in the electrophoresis, and visualized under UV light.

To sum up, the procedure can be simply separated into four steps: (1) preparation of materials to be loaded into wells and carried out of complexation, (2) preparation of agarose gel and loading of samples into wells, (3) running the samples at appropriate voltage and time, and (4) obtained data and identification of the optimum N/P ratio (Fig. 2).

1. Calculate the molecular weight and the number of amine groups of the cationic polymer (or look at the datasheet of your polymer if you purchase from a vendor) (see Note 6), i.e.;

(a) The molecular weight of a cationic polymer: $180,000.0 \mathrm{~g} / \mathrm{mol}$.

(b) Amine groups per the cationic polymer: 235 amines.

2. Determine the initial dose of the cationic polymer to be used and calculate the mole of the cationic polymer, i.e.;

(a) The cationic polymer dose: $1.0 \mathrm{mg}$.

(b) The number of the cationic polymer moles: $5.5 \times 10^{-9} \mathrm{~mol}$. 


\section{Table 1}

The siRNA/cationic polymer carrier complexation for different N/P ratios

\begin{tabular}{lllcll}
\hline $\begin{array}{l}\text { Well } \\
\text { number }\end{array}$ & $\begin{array}{l}\text { Treatment } \\
(\mathrm{N} / \mathrm{P})\end{array}$ & $\begin{array}{l}\text { Stock siRNA } \\
\text { solution }(\mu \mathrm{L})\end{array}$ & $\begin{array}{l}\text { Stock polymer } \\
\text { solution } \\
(\mu \mathrm{L})\end{array}$ & $\begin{array}{l}\text { Loading dye } \\
(\mu \mathrm{L})\end{array}$ & $\begin{array}{l}\text { Nuclease free } \\
\mathbf{H}_{\mathbf{2}} \mathbf{0}(\mu \mathrm{L})\end{array}$ \\
\hline 1 & DNA ladder & - & - & - & - \\
2 & Free siRNA & 1.0 & - & 4.0 & 15.0 \\
\hline 3 & $1.0 / 1.0$ & 1.0 & 1.6 & 4.0 & 13.4 \\
4 & $1.5 / 1.0$ & 1.0 & 2.4 & 4.0 & 12.6 \\
\hline 5 & $2.0 / 1.0$ & 1.0 & 3.2 & 4.0 & 11.8 \\
6 & $2.5 / 1.0$ & 1.0 & 4.0 & 4.0 & 11.0 \\
\hline 7 & $4.0 / 1.0$ & 1.0 & 6.4 & 4.0 & 8.6 \\
8 & $6.0 / 1.0$ & 1.0 & 9.6 & 4.0 & 5.4 \\
\hline 9 & Free & - & 10.6 & 4.0 & 5.4 \\
\hline
\end{tabular}

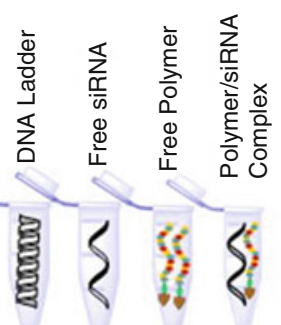

Step 1: Prepare polymer/siRNA complex at different N/P ratios and incubate for $30 \mathrm{~min}$.
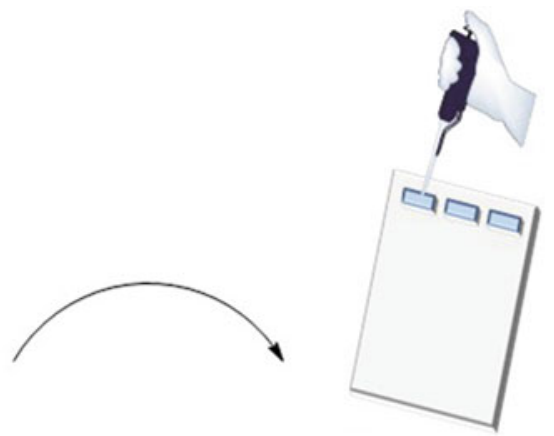

Step 2: Prepare the agarose gel and load each sample into wells.
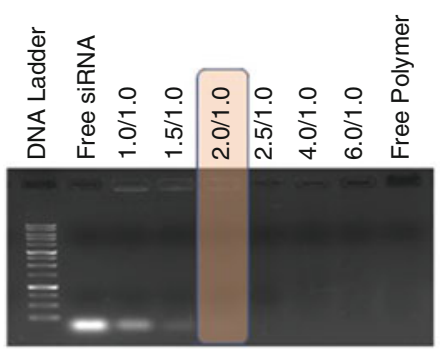

Step 4: Image analyze and determine the $\mathrm{N} / \mathrm{P}$ ratio

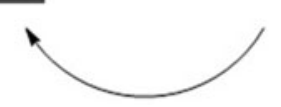

Step 3: With power supply for 60 $\min$ at $60 \mathrm{~V}$ initiate electrophoresis

Fig. 2 Brief summary of the creation stages of gel retardation assay 
3.1.2 Calculation of Phosphate Groups of SiRNAs

3.1.3 Calculation of N/P Ratios

\subsection{Preparation of 1\% Agarose Gel Electrophoresis}

3. Multiply the number of amine groups in the cationic polymer by the number of cationic polymer moles. This number will be the number of total amine moles.

(a) The mole of amine groups: $1.3 \times 10^{-6} \mathrm{~mol}$.

1. Calculate the average molecular weight of siRNAs ( see Note 7), i.e.;

(a) The average molecular weight of a siRNA molecule: $340.0 \mathrm{~g} / \mathrm{mol}$.

(b) siRNA consists of double stranded 21 bp so it has a total of $42 \mathrm{bp}$ unit/siRNA molecule.

(c) The molecular weight of 21 bp siRNA (siRNA molecule * number of bp * 2) $14,280.0 \mathrm{~g} / \mathrm{mol}$ $(340.0 * 21 * 2)$. This is the value used in the subsequent calculations.

2. Determine the initial dose of the siRNA to be used and calculate the mole of the siRNA.

(a) The siRNA dose: $0.7 \mu \mathrm{g}$.

(b) The number of siRNA moles: $4.9 \times 10^{-11} \mathrm{~mol}$.

3. Multiply the number of Phosphate $\left(\mathrm{PO}_{4}{ }^{3-}\right)$ groups in the siRNA to get the total number of phosphate groups.

(a) The mole of $\mathrm{PO}_{4}{ }^{3-}$ groups (siRNA moles * $\mathrm{nr} \mathrm{PO}_{4}{ }^{3-}$ groups): $2.06 \times 10^{-9} \mathrm{~mol}\left(4.9 \times 10^{-11} \mathrm{~mol} * 42\right)$.

One milligram of cationic polymer $\left(1.3 \times 10^{-6} \mathrm{~mol}\right.$ obtained from Subheadings 3.1.1-3.1.3) dissolved in $1.0 \mathrm{~mL}$ of distilled water as a stock solution. For the calculation of $1: 1 \mathrm{~N} / \mathrm{P}$ ratio, calculate the amount of amine groups in the polymer which equals to the same mole of $\mathrm{PO}_{4}{ }^{3-}$ groups $\left(2.1 \times 10^{-9}\right.$ mol obtained from the Subheadings 3.1.2 and 3.1.3). Based on this calculation, $1.60 \mu \mathrm{L}$ of the polymer solution is taken. For 1.5:1, 2:1, 2.5:1, 4:1, 6:1 N/P ratios, this volume is multiplied with $1.5,2.0,2.5,4.0$, and 6.0 , respectively (see Table 1$)$.

1. To prepare $1 \times$ TAE buffer, get $50.0 \mathrm{~mL}$ of $50 \times$ TAE buffer stock solution and complete to $1000.0 \mathrm{~mL}$ volume with distilled water in a beaker.

2. Add $1.0 \mathrm{~g}$ of agarose powder into $100.0 \mathrm{~mL}$ of $1 \times$ TAE buffer and mix it to make $1 \%$ agarose gel. After that, boil the agarose mixture in a microwave oven to melt it (see Note 8 ).

3. Cool the solution to approximately $50-60{ }^{\circ} \mathrm{C}$.

4. Add the RedSafe nucleic acid staining solution $(5.0 \mu \mathrm{L})($ see Note 9). 


\subsection{Loading siRNA/ Cationic Polymer Carrier Complex into $1 \%$ Agarose Gel}

5. Poured into a casting tray containing a sample comb and allowed to solidify at room temperature (see Note 10).

6. Remove the sample comb from the cooling casting tray (see Note 11).

1. Prepare mixture of nuclease-free water, polymer, and siRNA in separated microcentrifuge tubes as given in Table 1.

2. Allow $30 \mathrm{~min}$ for the complexation of siRNA/cationic polymer carrier.

3. Add $4.0 \mu \mathrm{L}$ of DNA gel loading dye to each centrifuge tube. The loading dye $(6 \times)$ is added to the gel for the visualization of siRNA during sample loading and running.

4. Load a total $20.0 \mu \mathrm{L}$ volume from each sample into agarose gel wells.

5. Set power supply at $60 \mathrm{~V}$ for $60 \mathrm{~min}$ ( see Note 12).

6. The electrophoretic mobility of the siRNAs of each sample is visualized under UV light (see Fig. 1).

\section{Notes}

1. Agarose gel electrophoresis of siRNA is performed using either TAE buffer or tris-borate-EDTA (TBE) buffer [39].

2. Wear a mask and gloves when preparing buffer agents. TAE buffer solution can be stored at room temperature for a month. In our laboratory, we prepare fresh solution every month.

3 . The most reliable strategy for TAE usage, prepare a fresh $1 \times$ TAE buffer for each time just before the experiment.

4. The percentage of agarose gels used is generally in the range of $0.2-3 \%$. This percentage could be changed based on the size of siRNA and total molecular weight of the carrier [40].

5. Allocate all the samples (i.e. siRNA) to avoid damaging the main source.

6. Calculation/determination of the molecular weight, chemical formulation, surface charge, and size of the polymer are carried out according to ${ }^{1} \mathrm{H}-\mathrm{NMR}$, zeta potential, and size analysis.

7. The average molecular weight of siRNA base is $340 \mathrm{~g} / \mathrm{mol}$. Average molecular weight of a double-stranded DNA (dsDNA) base pair and a single-stranded DNA (ssDNA) base pair are 600 and $330 \mathrm{~g} / \mathrm{mol}$, respectively [41].

8. Initially, the agarose solution is boiled for $45-60 \mathrm{~s}$ in the microwave at $180{ }^{\circ} \mathrm{C}$. If the agarose powder does not dissolve well, repeat the step for another 20-25 s until it totally dissolves. 
9. Instead of using RedSafe nucleic acid staining dye, ethidium bromide, bromophenol blue or xylene cyanole could be preferred [35].

10. The casting tray containing sample comb must be on a flat surface. Otherwise, the thickness of the gel may not be uniform. While pouring the solution, one should be careful about the formation of bubbles, which may affect the migration efficiency.

11. To solidify the gel, wait $1-1.5 \mathrm{~h}$ before removing the comb from the tray to ensure that the loading wells are intact and well-opened.

12. The optimum running time is $45-90 \mathrm{~min}$ to identify the $\mathrm{N} / \mathrm{P}$ ratio of siRNA/cationic polymer carrier complexation. In the case of gel electrophoresis is performed at a higher voltage, the running time is decreased. However, if the running time is increased that leads to heating up which leading to siRNA banding artifacts [39].

\section{Acknowledgments}

This work was supported by Scientific and Technological Research Council of Turkey (TUBITAK)-2515 COST Program Grant number: 118Z952 and Research Fund of Erciyes University (Project number: MAP-2020-9692).

\section{References}

1. Zhang X, Li DY, Reilly MP (2019) Long intergenic noncoding RNAs in cardiovascular diseases: challenges and strategies for physiological studies and translation. Atherosclerosis 281:180-188. https://doi.org/10. 1016/j.atherosclerosis.2018.09.040

2. Conejos-Sanchez I, Gallon E, Nino-Pariente A, Smith JA, De la Fuente AG, Di Canio L, Pluchino S, Franklin RJM, Vicent MJ (2019) Polyornithine-based polyplexes to boost effective gene silencing in CNS disorders. Nanoscale 12(11):6285-6299. https://doi.org/10. $1039 / \mathrm{c} 9 \mathrm{nr} 06187 \mathrm{~h}$

3. Liu T, Wang L, Xin H, Jin L, Zhang D (2020) Delivery systems for RNA interference-based therapy and their applications against cancer. Sci Adv Mater 12(1):75-86. https://doi.org/ $10.1166 / \mathrm{sam} .2020 .3694$

4. Subhan MA, Torchilin VP (2019) Efficient nanocarriers of siRNA therapeutics for cancer treatment. Transl Res 214:62-91. https://doi. org/10.1016/j.trsl.2019.07.006
5. Fire A, Xu S, Montgomery MK, Kostas SA, Driver SE, Mello CC (1998) Potent and specific genetic interference by double-stranded RNA in Caenorhabditis elegans. Nature 391(6669):806-811. https://doi.org/10. $1038 / 35888$

6. Dong Y, Siegwart DJ, Anderson DG (2019) Strategies, design, and chemistry in siRNA delivery systems. Adv Drug Deliv Rev 144: 133-147. https://doi.org/10.1016/j.addr. 2019.05.004

7. Kapadia CH, Luo B, Dang MN, Irvin-Choy ND, Valcourt DM, Day ES (2020) Polymer nanocarriers for MicroRNA delivery. J Appl Polym Sci 137(25):48651. https://doi.org/ $10.1002 /$ app.48651

8. Lin Y-X, Wang Y, Blake S, Yu M, Mei L, Wang H, Shi J (2020) RNA nanotechnologymediated cancer immunotherapy. Theranostics 10(1):281-299. https://doi.org/10.7150/ thno. 35568 
9. Karimi F, Azizi Jalilian F, Hossienkhani H, Ezati R, Amini R (2019) siRNA delivery technology for cancer therapy: promise and challenges. Acta Med Iran 57:83-93. https://doi. org/10.18502/acta.v57i2.1760

10. Tsouris V, Joo MK, Kim SH, Kwon IC, Won Y-Y (2014) Nano carriers that enable co-delivery of chemotherapy and RNAi agents for treatment of drug-resistant cancers. Biotechnol Adv 32(5):1037-1050. https://doi. org/10.1016/j.biotechadv.2014.05.006

11. Shirley JL, de Jong YP, Terhorst C, Herzog RW (2020) Immune responses to viral gene therapy vectors. Mol Ther 28(3):709-722. https://doi.org/10.1016/j.ymthe.2020. 01.001

12. Sabouri-Rad S, Oskuee RK, Mahmoodi A, Gholami L, Malaekeh-Nikouei B (2017) The effect of cell penetrating peptides on transfection activity and cytotoxicity of polyallylamine. Bioimpacts 7(3):139-145. https://doi.org/ 10.15171/bi.2017.17

13. Rezaee M, Oskuee RK, Nassirli H, MalaekehNikouei B (2016) Progress in the development of lipopolyplexes as efficient non-viral gene delivery systems. J Control Release 236:1-14. https://doi.org/10.1016/j.jconrel.2016. 06.023

14. Parashar D, Rajendran V, Shukla R, Sistla R (2020) Lipid-based nanocarriers for delivery of small interfering RNA for therapeutic use. Eur J Pharm Sci 142:105159. https://doi. org/10.1016/j.ejps.2019.105159

15. Jorge A, Pais A, Vitorino C (2020) Targeted siRNA delivery using lipid nanoparticles. Methods Mol Biol 2059:259-283

16. Liao X (2019) Development of a cationic polymer-based siRNA delivery system for the regeneration of tendon injury. University of East Anglia, Norwich

17. Qiu Y, Tam B, Chung WY, Mason J, Lam JK (2019) Relationship between the secondary structure of the peptide base siRNA carrier and effective gene silencing effect on lung epithelial cells. J Aerosol Med Pulmonary Drug Delivery 2:Al6-Al7

18. Cummings JC, Zhang H, Jakymiw A (2019) Peptide carriers to the rescue: overcoming the barriers to siRNA delivery for cancer treatment. Transl Res 214:92-104. https://doi. org/10.1016/j.trsl.2019.07.010

19. Pan J, Mendes LP, Yao M, Filipczak N, Garai S, Thakur GA, Sarisozen C, Torchilin VP (2019) Polyamidoamine dendrimers-based nanomedicine for combination therapy with siRNA and chemotherapeutics to overcome multidrug resistance. Eur J Pharm Biopharm 136:18-28. https://doi.org/10.1016/j.ejpb.2019.01.006

20. Laurini E, Marson D, Aulic S, Fermeglia M, Pricl S (2019) Evolution from covalent to selfassembled PAMAM-based dendrimers as nanovectors for siRNA delivery in cancer by coupled in silico-experimental studies. Part II: selfassembled siRNA Nanocarriers. Pharmaceutics ll(7):324. https://doi.org/10.3390/ pharmaceutics11070324

21. Jain A, Mahira S, Majoral J-P, Bryszewska M, Khan W, Ionov M (2019) Dendrimer mediated targeting of siRNA against polo-like kinase for the treatment of triple negative breast cancer. J Biomed Mater Res A 107(9):1933-1944. https://doi.org/10.1002/jbm.a.36701

22. Lu $\mathrm{Y}$, Zhong L, Jiang $\mathrm{Z}$, Pan $\mathrm{H}$, Zhang $\mathrm{Y}$, Zhu G, Bai L, Tong R, Shi J, Duan X (2019) Cationic micelle-based siRNA delivery for efficient colon cancer gene therapy. Nanoscale Res Lett 14(1):193. https://doi.org/10.1186/ sl1671-019-2985-z

23. Kandil R, Xie Y, Heermann R, Isert L, Jung K, Mehta A, Merkel OM (2019) Coming in and finding out: blending receptor-targeted delivery and efficient endosomal escape in a novel bio-responsive siRNA delivery system for gene knockdown in pulmonary $\mathrm{T}$ cells. Adv Ther 2(7):1900047. https://doi.org/10.1002/ adtp. 201900047

24. Prantner AM, Scholler N (2014) Biological barriers and current strategies for modifying nanoparticle bioavailability. J Nanosci Nanotechnol 14(1):115-125. https://doi.org/10. $1166 /$ jnn.2014.8899

25. Patil S, Gao Y-G, Lin X, Li Y, Dang K, Tian Y, Zhang W-J, Jiang S-F, Qadir A, Qian A-R (2019) The development of functional non-viral vectors for gene delivery. Int $\mathrm{J} \mathrm{Mol}$ Sci 20(21):5491. https://doi.org/10.3390/ ijms20215491

26. Chen J, Hessler JA, Putchakayala K, Panama BK, Khan DP, Hong S, Mullen DG, Dimaggio SC, Som A, Tew GN, Lopatin AN, Baker JR, Holl MMB, Orr BG (2009) Cationic nanoparticles induce nanoscale disruption in living cell plasma membranes. J Phys Chem B 113(32): 11179-11185. https://doi.org/10.1021/ jp9033936

27. Wei X, Shao B, He Z, Ye T, Luo M, Sang Y, Liang $X$, Wang $W$, Luo $S$, Yang $S$, Zhang $S$, Gong C, Gou M, Deng H, Zhao Y, Yang H, Deng S, Zhao C, Yang L, Qian Z, Li J, Sun X, Han J, Jiang C, Wu M, Zhang Z (2015) Cationic nanocarriers induce cell necrosis through impairment of $\mathrm{Na}+/ \mathrm{K}+$-ATPase and cause subsequent inflammatory response. Cell Res 
25(2):237-253. https://doi.org/10.1038/cr. 2015.9

28. Fröhlich E (2012) The role of surface charge in cellular uptake and cytotoxicity of medical nanoparticles. Int J Nanomedicine 7: 5577-5591. https://doi.org/10.2147/IJN. S36111

29. Durmaz YY, Lin Y-L, ElSayed MEH (2013) Development of degradable, $\mathrm{pH}$-sensitive star vectors for enhancing the cytoplasmic delivery of nucleic acids. Adv Funct Mater 23(31): 3885-3895. https://doi.org/10.1002/adfm. 201203762

30. Lv H, Zhang S, Wang B, Cui S, Yan J (2006) Toxicity of cationic lipids and cationic polymers in gene delivery. J Control Release 114(1): 100-109. https://doi.org/10.1016/j.jconrel. 2006.04.014

31. Scott V, Clark AR, Docherty K (1994) The gel retardation assay. In: Protocols for gene analysis. Springer, Berlin, pp 339-347

32. Hellman LM, Fried MG (2007) Electrophoretic mobility shift assay (EMSA) for detecting protein-nucleic acid interactions. Nat Protoc 2(8):1849

33. Helling RB, Goodman HM, Boyer HW (1974) Analysis of endonuclease R-EcoRI fragments of DNA from lambdoid bacteriophages and other viruses by agarose-gel electrophoresis. J Virol 14(5):1235-1244
34. Magdeldin S (2012) Gel electrophoresis: principles and basics. BoD-Books on Demand, Norderstedt

35. Chawla H (2002) Introduction to plant biotechnology. Routledge, Milton Park. https:// doi.org/10.1201/9781315275369

36. Tietz D (2012) Nucleic acid electrophoresis. Springer, Berlin

37. Loening UE (1968) Molecular weights of ribosomal RNA in relation to evolution. J Mol Biol 38(3):355-365. https://doi.org/ 10.1016/0022-2836(68)90391-4

38. Rio DC, Ares M Jr, Hannon GJ, Nilsen TW (2010) Nondenaturing agarose gel electrophoresis of RNA. Cold Spring Harb Protoc 2010(6):pdb.prot5445. https://doi.org/10. $1101 /$ pdb.prot5445

39. Sanderson BA, Araki N, Lilley JL, Guerrero G, Lewis LK (2014) Modification of gel architecture and TBE/TAE buffer composition to minimize heating during agarose gel electrophoresis. Anal Biochem 454:44-52. https:// doi.org/10.1016/j.ab.2014.03.003

40. Murphy D, Carter DA, Evans MJ (1993) Transgenesis techniques: principles and protocols. Springer, Berlin

41. He F (2011) DNA molecular weight calculation. Bio-Protocol 1(6):e46. https://doi.org/ 10.21769/BioProtoc. 46

Open Access This chapter is licensed under the terms of the Creative Commons Attribution 4.0 International License (http://creativecommons.org/licenses/by/4.0/), which permits use, sharing, adaptation, distribution and reproduction in any medium or format, as long as you give appropriate credit to the original author(s) and the source, provide a link to the Creative Commons license and indicate if changes were made.

The images or other third party material in this chapter are included in the chapter's Creative Commons license, unless indicated otherwise in a credit line to the material. If material is not included in the chapter's Creative Commons license and your intended use is not permitted by statutory regulation or exceeds the permitted use, you will need to obtain permission directly from the copyright holder. 